\section{ECONOMICS}

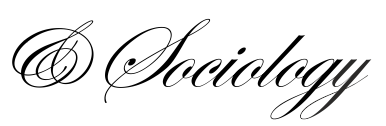

Vveinhardt, J., Deikus, M., \& Jezerskè, Ž. (2021). Workplace violence: Gender and age factors in the search for religious spiritual assistance. Economics and Sociology: 14(4), 283-296. doi:10.14254/2071-789X.2021/14-4/16

\title{
WORKPLACE VIOLENCE: GENDER AND AGE FACTORS IN THE SEARCH FOR RELIGIOUS SPIRITUAL ASSISTANCE
}

Jolita Vveinhardt

Vytautas Magnus University,

Kaunas, Lithuania

E-mail: jolita.vveinhardt@vdu.lt

ORCID 0000-0001-6231-9402

\author{
Mykolas Deikus \\ Vytautas Magnus University, \\ Kaunas, Litbuania \\ E-mail:mykolas.deikus@vdu.lt \\ ORCID 0000-0003-1718-7740
}

Živilè Jezerskè

Vilnius Gediminas Technical

University, Vilnius, Litbuania

E-mail:

zivile.jezerske@,vilniustech.lt

ORCID 0000-0002-3137-8159

Received: May, 2021

1st Revision: November, 2021

Accepted: December, 2021

DOI: $10.14254 / 2071$ -

789X.2021/14-4/16

JEL Classification: M12, M14, M19
ABSTRACT. Although there is ample literature on violence in the workplace, the opportunities for religious organizations to participate in providing assistance to victims remain little investigated. Therefore, in this article, we analyse the circumstances that promote the search for religious spiritual assistance and how this corresponds to the expectations of victims of violence in the workplace. Based on the results of the empirical study, we demonstrate that despite secularization trends, a sufficient value-based foundation still remains, which makes assistance provided by religious organizations potentially acceptable to victims. Contrary to what could have been expected, men reported being victims of violence more often, and the differences between individual age groups were statistically insignificant. The age variable was important only for obtaining information on this type of assistance. Women, meanwhile, emphasized the importance of religious values more than men did, but at the same time, they also showed greater sensitivity to the contextual circumstances on which the decision to seek religious assistance depended. This article presents only part of the results of a broader scientific study, one that is exclusively related to victims' gender and age.

Keywords: workplace violence, victim, gender, female victims, male victims, age, religion, spiritual assistance

\section{Introduction}

Research conducted over the last decade shows that various forms of violence remain a relevant or even growing problem in Europe (Fischer, Van Reemst \& De Jong, 2016; Spector, Zhou, \& Che, 2014; Van den Bossche et al., 2013). According to the research results of Van den Bossche et al. (2013), although violence was related to employee gender, age, sector and work settings, change in the European labour market and the working environment could not explain the increase in violence. In addition, Spector et al. (2014) compared the nature of violence in different regions of the world. They noted that physical violence and sexual 
harassment particularly stood out in English-speaking countries. Of course, it cannot be ruled out that the figures pertain to a greater focus on sexual harassment and victims' better ability to identify the impermissible behaviour, but Salin (2015) maintains that the victim's gender remains one of the risk factors, while differences in negative experiences between genders can be explained by the conception of the power of gender equality, the gender role socialization theory, and the social identity theory (Salin \& Hoel, 2013). Furthermore, some studies demonstrate that gender, like age, is related to the extent of experienced damage to health. For example, the consequences of workplace violence include depression, fear, more frequent absenteeism from work due to illness, and lower job satisfaction (Lanctôt \& Guay, 2014). The study of Friis et al. (2018) also demonstrates that vulnerable women over the age of 40 are at greater risk of experiencing adverse health effects and being absent from work due to experienced violence.

Victims are usually offered psychological assistance or inpatient care in medical facilities, but in this context, it is important to note that perception of the meaning of experienced suffering, spiritual growth, the sense of community support are important conditions for restoring internal balance, re-establishing broken social ties, and living a fullfledged life that is related to involvement of religious communities in the provided assistance. Research conducted in recent years shows that integration of religious spiritual assistance reflects a holistic approach to a treatment, meeting the person's spiritual needs (e.g., Abbott, 2012; Barnes, 2010; Schultz et al., 2020), and that the person's religiosity also influences the nature of chosen assistance (Crosby \& Bossley, 2012; Moreno et al., 2017). Although research on the impact of religiosity on persons experiencing violence in the workplace is not abundant, Jalali et al. (2020) note that the victim's religiosity plays a certain protective role. However, due to the lack of research, it is not yet entirely clear how spiritual assistance resources of religious communities could be employed for provision of assistance to the victims of workplace violence. Although such assistance to people who have found themselves in various crises is provided by the clergy, secular spiritual counsellors and spiritual assistants, there is still a need for greater clarity on how this assistance responds to the expectations and needs of affected employees of different genders and ages. This would enable to improve the quality of assistance and increase the involvement of religious communities. In this article, we seek to identify the circumstances promoting the search for religious spiritual assistance and how this meets the expectations of victims of workplace violence. First, the research carried out to date will be discussed. It is shown that religious spiritual assistance does not have to duplicate psychological assistance but can organically complement it when it comes to victims with religious preferences. This will be followed by a presentation of a structure of the instrument used for the empirical research, organization and course of the study. We will show that victims of violence at work are positive about the assistance of religious communities, and a share of them do not rule out the possibility of such help even if they are faithless. Finally, we will highlight key aspects related to gender and age that are important for expanding assistance of religious communities to victims who have suffered physical and psychological violence in the workplace.

\section{Literature review}

\subsection{Religious spiritual assistance}

Religious communities and their NGOs have traditionally focused on religious moral education, palliative care, and social support (Opatrný, 2020; Stirling, 2019). These are probably the most visible aspects of the activities of these communities, but the concept of 
spiritual assistance is much broader. Therefore, we will further briefly discuss the specificity of religious spiritual assistance and then, social and demographic variables that may affect the search for help.

Definitions of religious spiritual assistance. Doehring (1992) emphasizes that the main aim of assistance should be empowerment and liberation, which is particularly important while viewing pastoral care from a feminist approach. In this case, two trends of such assistance according to assistants' professionalism and the content of assistance must be distinguished. Professional spiritual counsellors and assistants who use knowledge and methods of the psychology science in their activities should be attributed to the first group (Gubi, 2011; Hagmaier, 1963; Turner, 2017). According to Burton (2004), helping to overcome spiritual pain, the focus is on restoration of interpersonal relationships, the development of the relationship with God in the Spirit, listening, sagacity, and spiritual growth. Clinebell (1998), in turn, distinguishes two levels in the assistance, namely, helping people solve arisen problems or crises and then encouraging them to analyse fundamental value-related and spiritual problems that make their current problems painful to them. The second group of persons providing assistance consists of secular members of the religious community who provide moral support and involve victims in the life of their community, this way helping to recover from experienced traumas (more: Deventer-Noordeloos et al., 2018; Schuster et al., 2001). Of course, this separation is more technical, as efficient assistance requires reconciled efforts of both professionals and the community, but this helps to understand the specificity of religious spiritual assistance. Therefore, both the competencies of professional assistants and the community's readiness and ability to accept the victim are important factors.

Religiosity and demographic factors. Other important factors that may influence the use of religious spiritual assistance are the person's religiosity as well as gender and age variables of those seeking spiritual assistance (Al-Krenawi et al., 2004; Mitchell \& Baker, 2000; Mayers et al., 2007). On the one hand, in European societies, a significant role is played by religious identity, as demonstrated by the study of Fleischmann and Phalet (2018). This insight is supported by van der Noll et al. (2018) who argue that, contrary to the widespread belief that Europe is secular, religion and, in particular, a specific Christian understanding of religiosity remain important to Europeans' identity. However, it has been noted that support for manifestation of religious identity was the weakest in four countries: Lithuania, East Germany, Northern Ireland and France (wearing visible religious symbols in the workplace was acceptable for less than 40 per cent of respondents). Due to the lack of data from Lithuania and several other countries, van der Noll et al. (2018) did not analyse religious values, but other data suggest that identification with a particular religion does not necessarily reflect adherence to the dogmas of that religion (Guetto et al., 2015).

Religiosity, on the other hand, depends on variables such as gender and age. The results of the study conducted by Breen and Healy (2014) in Ireland have shown that although public religiosity was higher than the European average, strong globalization trends emerged. Older, less educated, unemployed rural women were still most religious, while at the other end of the spectrum, the most secular were younger, educated, unemployed urban men. Comparing secularization trends in Spain and Poland, it was observed that in both countries, the younger generation representatives had been less religious than the older ones (Requena \& Stanek, 2013). For comparison, women and older adults in Brazil distinguished themselves by stronger religiosity, more distinct signs of spirituality; similar trends were also observed in the study conducted in the United States (Lee, 2011). These trends are significant in that the search for assistance pertains not only to the person's religious expectations but also to gender (Brenner et al., 2018; Keating \& Fretz, 1990). For example, Brenner et al. (2018) have found that men distinguishing themselves by high levels of religious commitment and self-respect sought help 
less often. This is explained by the fact that the religious persons' attitude to assistance may be influenced by their self-respect. Besides, the attitude of the clergy to the nature of the provided assistance is also important. In the study conducted by Sørgaard and Sørensen (2004) in Norway, priests stated that their work with persons who had psychological problems was grounded on the "holistic" conception of the human being, the lack of which in secular treatment practice resulted in people's reluctance to refer to secular professionals. The results of another study conducted in Portugal show that secular members of the religious community are also more positively biased towards religious assistance resources. According to Freire et al. (2016), after experiencing psychological adversity, research participants (mean age - 41,4) reported that they first had referred to the resources of their religious community (e.g., God, religious leaders, family) rather than secular mental health professionals, who had been understood as the last alternative.

\subsection{Violence at work by gender and age}

Research shows that more often, victims of workplace attacks are persons with certain demographic characteristics. Jaradat et al. (2016) interviewed 372 nurses, more than a quarter of whom had experienced physical and psychological aggression. In this context, greater impact of physical and verbal aggression was more often mentioned by younger women. These findings are in line with the results obtained in survey in SMEs segment by Bilan et al. (2020), particularly, regarding the career opportunities and remuneration, which are important in subjective perception of quality of life of younger employees (Tvaronavičienè et al., 2021). To some extend negative consequences for women rights violation can be mitigated using technologies of telework (Raišienè et al., 2021). Meanwhile, the study conducted in Italy has shown that women experienced more verbal violence than men, who experienced physical violence more often (Maran et al., 2019). Nevertheless, trends of greater long-term harm to women from violence were observed by the authors of studies conducted in Sweden (Emdad et al., 2012) and China (Li et al., 2019), although some other studies found no significant differences between negative experiences of men and women (Lange et al., 2019; Vartia \& Hyyti, 2002), contrary to age groups. For example, the study carried out in Germany by Lange et al. (2019) has shown that younger employees suffered from the negative type managerial actions more often. The authors have concluded that what matters is not so much the biological age as the socioeconomic status and the balance of power, related to experience in the organization, which is more characteristic of older employees. The fact that the age group is related not only to the frequency of violence but also to the nature of violence is demonstrated in the study of Fasanya and Dada (2015). The authors found that the group of persons from 36 to 45 years old had experienced more bullying and physical coercion compared with other groups and that verbal abuse had been more common among employees over the age of 46 . Meanwhile, employees between 26 and 35 years old suffered most from constant criticism. In addition, it must be noted that the experiences of the representatives of the same age group may also differ. For example, the authors of the study carried out in the United States found that young employees at varying stages of development might understand and respond to workplace violence differently (employees aged 15-24 were interviewed) (Brown et al., 2020).

Although the literature does not provide unambiguous answers, it can still be assumed that younger individuals are at higher risk and that gender and age are related to different responses to attacks. For example, after investigating experiences and reactions to the stress resulting from violence of persons born in 1964-1983 and 1984-2003 in the Turkish nursing sector, it was found that although the older generation representatives had experienced violence significantly more rarely than persons younger than them $(38,3$ per cent and 57,9 per cent, 
respectively), they had demonstrated helplessness and sought social support more often, unlike the younger ones (Cetinkaya et al., 2018). In addition, a survey of individuals whose average age is 40,8 has found that men sought help more rarely compared with women, which is associated with their higher status perceived by silence, guaranteeing a more favourable situation (Mulder et al., 2014). Meanwhile, women themselves are more likely to help victims (Mulder et al., 2017), particularly, using technological means of communication in order to create the nets allow to avoid the violation of their rights (Tenhunen, 2019). It has also been found that in response to violence at work, men choose more active, assertiveness-based strategies and are more inclined to analyse their behaviour (Jóhannsdóttir \& Ólafsson, 2004), which is explained by gender-related social norms (Notelaers et al., 2019). Thus, all of it allows to assume that female victims and older victims may be more likely to take interest in assistance possibilities.

\section{Methodological approach}

Structure of the instrument. The empirical study was conducted choosing a questionnaire survey method, employing the questionnaire compiled by Vveinhardt and Deikus (2021) "Motives of Persons Aggrieved at Work for Seeking Spiritual Assistance (MP-SSA40)". The MP-SSA-40 is composed of 4 scales: DR-10-Destructive relationships, $\alpha=0.872$ (example of the item "I felt lonely because others held aloof from me, avoided communicating"), VL-12-Values, $\alpha=0.935$ (example of the item "God is important in my life"), SA-6-Service awareness, $\alpha=0.903$ (example of the item "It fell to me to read ads at a religious community home"), MT-12-Motives, $\alpha=0.936$ (example of the item "I would address because the service is free"). The questionnaire consists of 40 items on the Likert scale (when value 1 means strongly disagree; and 5, strongly agree).

Organization and course of the research. The questionnaire survey was conducted in Lithuania in the first quarter of 2020. It was attended by 463 adult working persons aged from 18 to $65+$ (in 2021, the retirement age for women is 63 years and 4 months; for men, 64 years and 2 months). Figure 1 shows the distribution of research participants by gender and age.

\begin{tabular}{|c|c|c|}
\hline Females $(n=280)$ & & Males $(n=183)$ \\
\hline Distribution of women by age & Dis & bution of men by age \\
\hline $18-24$ years old, $n=38$ & 18 & years old, $n=29$ \\
\hline $25-34$ years old, $\mathrm{n}=71$ & 25 & years old, $\mathrm{n}=54$ \\
\hline $35-44$ years old, $n=60$ & 35 & years old, $\mathrm{n}=33$ \\
\hline $45-54$ years old, $n=64$ & 45 & years old, $\mathrm{n}=35$ \\
\hline $55-65$ years old and older, $n=47$ & 55 & years old and older, $n=32$ \\
\hline
\end{tabular}

Figure 1. Distribution of research participants by gender and age Source: own data

\section{Conducting research and results}

The ANOVA test results show that men experienced violence in the workplace more often than women and that the differences between the two gender groups were statistically 
significant and reliable, while no such differences were identified with regard to age. In other words, with the reasons remaining the same, violence tends to be more common against male representatives. Besides, several relevant trends have emerged, showing what things are considered important when the representatives of different genders are choosing religious spiritual assistance. First, although women emphasized the importance of information about assistance more often, no statistically significant differences were found. Second, women accentuated personal values more often and tended to be more supportive of the values disseminated by religious organizations, which shows that this may influence a more favourable attitude towards seeking this specific help. Third, both circumstances and the interpersonal relationship with the person providing assistance were more important to women than to men (the differences are statistically significant). That is, despite a greater propensity for religious spiritual assistance, women who have experienced violence are more sensitive while responding to contextual circumstances that may have a significant impact on their resolve (Table 1).

Table 1 . ANOVA test by gender at the subscale level

\begin{tabular}{|c|c|c|c|c|c|c|c|c|}
\hline \multirow{2}{*}{ 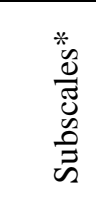 } & \multicolumn{2}{|c|}{$\begin{array}{c}\text { Males } \\
(\mathrm{N}=183)\end{array}$} & \multicolumn{2}{|c|}{$\begin{array}{l}\text { Females } \\
(\mathrm{N}=280)\end{array}$} & \multicolumn{2}{|c|}{ ANOVA test results } & \multicolumn{2}{|c|}{ Contrast $(-1,1)$} \\
\hline & Mean & $S D$ & Mean & $S D$ & $F$ & $p$ & $\begin{array}{c}\text { Contrast } \\
\text { value }\end{array}$ & $\begin{array}{c}\text { Contrast } \\
\text { value, } \\
p\end{array}$ \\
\hline DRA & 2.07 & 0.85 & 1.89 & 0.74 & 5.763 & $0.017 *$ & -0.180 & $0.020 *$ \\
\hline DRC & 1.57 & 0.69 & 1.63 & 0.77 & 0.816 & 0.367 & 0.063 & 0.356 \\
\hline VLP & 2.77 & 1.03 & 3.15 & 0.91 & 17.104 & $0.0001 * *$ & 0.378 & $0.0001 * *$ \\
\hline VLO & 2.92 & 1.02 & 3.25 & 0.85 & 13.972 & $0.001 * *$ & 0.327 & $0.001 * *$ \\
\hline SAK & 2.58 & 1.00 & 2.75 & 0.86 & 3.771 & 0.053 & 0.170 & 0.060 \\
\hline MTC & 3.03 & 1.06 & 3.43 & 0.88 & 18.572 & $0.0001 * *$ & 0.392 & $0.0001 * *$ \\
\hline MTR & 2.53 & 1.15 & 2.85 & 1.00 & 10.109 & $0.002 * *$ & 0.322 & $0.002 * *$ \\
\hline
\end{tabular}

Source: own compilation

* DRA - Destructive actions; DRC - Causes of destructive actions; VLP - Personal values; VLO - Values of religious organisations; SAK - Knowledge of assistance provided by religious organisations; MTC - Motives determined by circumstances; MTR - Motives determined by the relation. ${ }^{*}$ statistical significance level $\alpha=0.05 ; * *$ statistical significance level $\alpha=0.01$.

Using the Chi-square test criterion, it was sought to find out differences in men's and women's responses to subscale items according to whether workplace violence had been experienced. It was found that in this case, the gender criterion was significant only to personal values, approval of values of the religious organization, and circumstances influencing the decision to seek religious spiritual assistance (Table 2). That is, the values and religious practices declared by the religious organization are more important to women who have experienced violence than to men, as are the motives for seeking help, determined by circumstances. No statistically significant differences were found in the remaining subscales, which means that this is similarly important or unimportant for both men and women. 
RECENT ISSUES IN SOCIOLOGICAL RESEARCH

Table 2. Chi-square criterion test by gender

\begin{tabular}{|c|c|c|c|c|c|c|c|}
\hline \multirow[t]{2}{*}{ Subscales* } & \multirow{2}{*}{$\begin{array}{l}\text { No/ } \\
\text { Yes }\end{array}$} & \multicolumn{2}{|c|}{$\begin{array}{l}\text { Males } \\
(\mathrm{N}=183)\end{array}$} & \multicolumn{2}{|c|}{$\begin{array}{l}\text { Females } \\
(\mathrm{N}=280)\end{array}$} & \multicolumn{2}{|c|}{$\begin{array}{l}\text { Chi-square criterion test } \\
\text { results }\end{array}$} \\
\hline & & $N$ & $\%$ & $N$ & $\%$ & $\gamma 2$ & $P$ \\
\hline \multirow{2}{*}{ DRA } & No & 121 & 66.1 & 195 & 69.6 & \multirow{2}{*}{0.634} & \multirow{2}{*}{0.426} \\
\hline & Yes & 62 & 33.9 & 85 & 30.4 & & \\
\hline \multirow{2}{*}{ DRC } & No & 162 & 88.5 & 237 & 84.6 & \multirow{2}{*}{1.400} & \multirow{2}{*}{0.237} \\
\hline & Yes & 21 & 11.5 & 43 & 15.4 & & \\
\hline \multirow{2}{*}{ VLP } & No & 47 & 25.7 & 34 & 12.1 & \multirow{2}{*}{14.057} & \multirow[b]{2}{*}{$0.001 * *$} \\
\hline & Yes & 136 & 74.3 & 246 & 87.9 & & \\
\hline \multirow{2}{*}{ VLO } & No & 45 & 24.6 & 40 & 14.3 & \multirow{2}{*}{7.840} & \multirow{2}{*}{$0.005^{* *}$} \\
\hline & Yes & 138 & 75.4 & 240 & 85.7 & & \\
\hline \multirow{2}{*}{ SAK } & No & 91 & 49.7 & 139 & 49.6 & \multirow{2}{*}{0.003} & \multirow{2}{*}{0.986} \\
\hline & Yes & 92 & 50.3 & 141 & 50.4 & & \\
\hline \multirow{2}{*}{ MTC } & No & 50 & 27.3 & 46 & 16.4 & \multirow{2}{*}{7.991} & \multirow{2}{*}{$0.005^{* *}$} \\
\hline & Yes & 133 & 72.7 & 234 & 83.6 & & \\
\hline \multirow{2}{*}{ MTR } & No & 107 & 58.5 & 144 & 51.4 & \multirow{2}{*}{2.211} & \multirow{2}{*}{0.137} \\
\hline & Yes & 76 & 41.5 & 436 & 48.6 & & \\
\hline
\end{tabular}

Source: own compilation

Notes: No - did not experience destructive relationships; Yes - experienced destructive relationships.

* DRA - Destructive actions; DRC - Causes of destructive actions; VLP - Personal values; VLO - Values of religious organisations; SAK - Knowledge of assistance provided by religious organisations; MTC - Motives determined by circumstances; MTR - Motives determined by the relation. ${ }^{* *}$ statistical significance level $\alpha=0.01$.

Although no statistically significant differences were found in the measured characteristics on the four scales between different age groups, some differences emerged at the subscale level. Test results show that the manifestation of personal values differs significantly depending on the age group (the lowest values were found in the age group of 1824 years - mean 2.89; and the highest, in the group of 55-65 years and older - mean 3.20). In addition, it can be seen that the importance of religious values is increasing with each older age group. The differences are shown by the results of the analysis of variance, in which case the contrast is statistically significantly different from zero. Hence, in all remaining aspects, statistically significant differences between the means were not identified and measured features in five age groups were similar (Tables 3-4).

Table 3. ANOVA test at scale level by age groups

\begin{tabular}{|c|c|c|c|c|c|c|c|c|c|c|c|c|}
\hline \multirow[t]{2}{*}{ Scales* } & \multicolumn{2}{|c|}{$\begin{array}{c}\text { 18-24 years } \\
\text { old } \\
(\mathrm{N}=67)\end{array}$} & \multicolumn{2}{|c|}{$\begin{array}{c}25-34 \text { years } \\
\text { old } \\
(\mathrm{N}=125)\end{array}$} & \multicolumn{2}{|c|}{$\begin{array}{c}35-44 \text { years } \\
\text { old } \\
(\mathrm{N}=93)\end{array}$} & \multicolumn{2}{|c|}{$\begin{array}{c}45-54 \text { years } \\
\text { old } \\
(\mathrm{N}=99)\end{array}$} & \multicolumn{2}{|c|}{$\begin{array}{l}\text { 55-65 years } \\
\text { old and older } \\
(\mathrm{N}=79)\end{array}$} & \multicolumn{2}{|c|}{$\begin{array}{l}\text { ANOVA test } \\
\text { results }\end{array}$} \\
\hline & Mean & $S D$ & Mean & $S D$ & Mean & $S D$ & Mean & $S D$ & Mean & $S D$ & $F$ & $p$ \\
\hline DR & 1.78 & 0.76 & 1.72 & 0.59 & 1.86 & 0.70 & 1.82 & 0.72 & 1.75 & 0.65 & 0.672 & 0.612 \\
\hline VL & 3.02 & 0.94 & 2.88 & 0.88 & 3.16 & 0.93 & 3.12 & 0.90 & 3.20 & 0.88 & 2.143 & 0.075 \\
\hline SA & 2.55 & 0.98 & 2.61 & 0.88 & 2.75 & 0.96 & 2.69 & 0.89 & 2.82 & 0.93 & 1.093 & 0.359 \\
\hline MT & 3.01 & 0.96 & 2.90 & 0.94 & 3.06 & 1.08 & 3.02 & 0.88 & 3.04 & 0.88 & 0.496 & 0.739 \\
\hline
\end{tabular}

Source: own compilation

*DR - Destructive relationships; VL - Values; SA - Service awareness; MT - Motives. 
Table 4. ANOVA test at subscale level by age groups

\begin{tabular}{|c|c|c|c|c|c|c|c|c|c|c|c|c|c|c|}
\hline \multirow{2}{*}{ 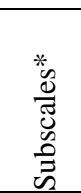 } & \multicolumn{2}{|c|}{$\begin{array}{c}\text { 18-24 years } \\
\text { old } \\
(\mathrm{N}=67)\end{array}$} & \multicolumn{2}{|c|}{$\begin{array}{c}25-34 \text { years } \\
\text { old } \\
(\mathrm{N}=125)\end{array}$} & \multicolumn{2}{|c|}{$\begin{array}{c}\text { 35-44 years } \\
\text { old } \\
(\mathrm{N}=93)\end{array}$} & \multicolumn{2}{|c|}{$\begin{array}{c}45-54 \text { years } \\
\text { old } \\
(\mathrm{N}=99)\end{array}$} & \multicolumn{2}{|c|}{$\begin{array}{l}55-65 \text { years } \\
\text { old and older } \\
(\mathrm{N}=79)\end{array}$} & \multicolumn{2}{|c|}{$\begin{array}{l}\text { ANOVA } \\
\text { test results }\end{array}$} & \multicolumn{2}{|c|}{ Contrast $(-1,1)$} \\
\hline & Mean & $S D$ & Tean & $S D$ & Iean & $S D$ & lean & $S D$ & Mean & $S D$ & $F$ & $n$ & $\begin{array}{c}\text { Contrast } \\
\text { value }\end{array}$ & $\begin{array}{l}\text { Contrast } \\
\text { value, } p\end{array}$ \\
\hline DRA & 8 & & 3 & & 99 & & & & 2. & 76 & & & & \\
\hline C & 57 & & 52 & & 73 & 0.7 & 99 & & 1.48 & 0.70 & & & & \\
\hline VLP & 89 & 1.02 & 2.75 & 0.9 & 3.18 & 0.9 & 3.07 & 0.9 & 3.20 & 0.91 & 4.036 & $0.003 *$ & & $0.004 * *$ \\
\hline $\mathrm{O}$ & & & 0 & & & & & & 3.20 & 0.93 & & & & \\
\hline & & & & & .1 & .9 & 2.69 & & 2.82 & 0.93 & & & & \\
\hline $\mathrm{C}$ & & 1.00 & 23 & 0.3 & 0.01 & & 3.26 & & 3.29 & 0.85 & & & & \\
\hline MTR & 2.70 & 1.13 & 2.57 & 1.07 & 2.82 & 1.16 & 2.79 & 0.99 & 2.80 & 1.06 & 0.959 & 0.430 & 0.319 & 0.275 \\
\hline
\end{tabular}

Source: own compilation

* DRA - Destructive actions; DRC - Causes of destructive actions; VLP - Personal values; VLO - Values of religious organisations; SAK - Knowledge of assistance provided by religious organisations; MTC - Motives determined by circumstances; MTR - Motives determined by the relation. ${ }^{* *}$ statistical significance level $\alpha=0.01$.

According to five age groups, statistically significant differences were found only on the subscale of knowledge of the provided spiritual assistance. Persons aged 25-34 are least aware of the services provided by religious organizations, while the oldest group of investigated persons is most aware of the said services. It should be noted that the youngest persons who have experienced violence at work constitute the second group in terms of awareness of spiritual assistance (Table 5). However, the ways in which information reaches persons vary. According to the approval at the level of individual items, it can be seen that the representatives of this group more often received information about the assistance by word-of-mouth when acquaintances (43.3 per cent) told about it, similarly to the group of the oldest persons (44.3 per cent). In addition, the latter received more information from secular rather than religious media (41.8 per cent and 31.6 per cent, respectively). Interestingly, comparing the ways of obtaining information, the lowest percentages in both groups fell on dissemination of information in community gatherings (the youngest persons -13.4 per cent and the oldest -20.3 per cent) and on receiving information directly from the clergy (the youngest persons -32.8 per cent and the oldest -24.1 per cent).

Table 5. Chi-square criterion test by age groups

\begin{tabular}{|c|c|c|c|c|c|c|c|c|c|c|c|c|c|}
\hline \multirow[t]{2}{*}{ 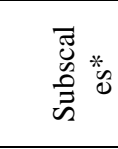 } & \multirow[t]{2}{*}{$\begin{array}{l}\mathrm{No} / \\
\mathrm{Yes}\end{array}$} & \multicolumn{2}{|c|}{$\begin{array}{c}18-24 \text { years } \\
\text { old } \\
(\mathrm{N}=67)\end{array}$} & \multicolumn{2}{|c|}{$\begin{array}{c}25-34 \text { years old } \\
(\mathrm{N}=125)\end{array}$} & \multicolumn{2}{|c|}{$\begin{array}{c}\text { 35-44 years } \\
\text { old } \\
(\mathrm{N}=93)\end{array}$} & \multicolumn{2}{|c|}{$\begin{array}{c}\text { 45-54 years } \\
\text { old } \\
(\mathrm{N}=99)\end{array}$} & \multicolumn{2}{|c|}{$\begin{array}{c}\text { 55-65 years } \\
\text { old and older } \\
\quad(\mathrm{N}=79)\end{array}$} & \multicolumn{2}{|c|}{$\begin{array}{c}\text { Chi - square criterion } \\
\text { test results }\end{array}$} \\
\hline & & $N$ & $\%$ & $N$ & $\%$ & $N$ & $\%$ & $N$ & $\%$ & $N$ & $\%$ & $\chi^{2}$ & $P$ \\
\hline \multirow{2}{*}{ DRA } & No & 42 & 62.7 & 96 & 76.8 & 61 & 65.6 & 64 & 64.6 & 53 & 67.1 & \multirow{2}{*}{6.120} & \multirow{2}{*}{0.190} \\
\hline & Yes & 25 & 37.3 & 29 & 23.2 & 32 & 34.4 & 35 & 35.4 & 26 & 32.9 & & \\
\hline \multirow{2}{*}{ DRC } & No & 57 & 85.1 & 106 & 84.8 & 83 & 89.2 & 84 & 84.8 & 69 & 87.3 & \multirow{2}{*}{1.240} & \multirow{2}{*}{0.871} \\
\hline & Yes & 10 & 14.9 & 19 & 15.2 & 10 & 10.8 & 15 & 15.2 & 10 & 12.7 & & \\
\hline \multirow{2}{*}{ VLP } & $\mathrm{No}$ & 12 & 17.9 & 24 & 19.2 & 11 & 11.8 & 24 & 24.2 & 10 & 12.7 & \multirow{2}{*}{6.732} & \multirow{2}{*}{0.151} \\
\hline & Yes & 55 & 82.1 & 101 & 80.8 & 82 & 88.2 & 75 & 75.8 & 69 & 87.3 & & \\
\hline \multirow{2}{*}{ VLO } & No & 7 & 10.4 & 27 & 21.6 & 17 & 18.3 & 22 & 22.2 & 12 & 15.2 & \multirow{2}{*}{5.189} & \multirow{2}{*}{0.268} \\
\hline & Yes & 60 & 89.6 & 98 & 78.4 & 76 & 81.7 & 77 & 77.8 & 67 & 84.8 & & \\
\hline \multirow{2}{*}{ SAK } & $\mathrm{No}$ & 31 & 46.3 & 76 & 60.8 & 48 & 51.6 & 49 & 49.5 & 26 & 32.9 & \multirow{2}{*}{15.521} & \multirow{2}{*}{$0.004 * *$} \\
\hline & Yes & 36 & 53.7 & 49 & 39.2 & 45 & 48.4 & 50 & 50.5 & 53 & 67.1 & & \\
\hline \multirow{2}{*}{ MTC } & $\mathrm{No}$ & 10 & 14.9 & 31 & 24.8 & 20 & 21.5 & 22 & 22.2 & 13 & 16.5 & \multirow{2}{*}{3.680} & \multirow{2}{*}{0.451} \\
\hline & Yes & 57 & 85.1 & 94 & 75.2 & 73 & 78.5 & 77 & 77.8 & 66 & 83.5 & & \\
\hline \multirow{2}{*}{ MTR } & No & 28 & 41.8 & 76 & 60.8 & 48 & 51.6 & 58 & 58.6 & 41 & 51.9 & \multirow{2}{*}{7.536} & \multirow{2}{*}{0.110} \\
\hline & Yes & 39 & 58.2 & 49 & 39.2 & 45 & 48.4 & 41 & 41.4 & 38 & 48.1 & & \\
\hline
\end{tabular}

Source: own compilation 
Notes: No - did not experience destructive relationships; Yes - experienced destructive relationships.

* DRA - Destructive actions; DRC - Causes of destructive actions; VLP - Personal values; VLO - Values of religious organisations; SAK - Knowledge of assistance provided by religious organisations; MTC - Motives determined by circumstances; MTR - Motives determined by the relation. ${ }^{* *}$ statistical significance level $\alpha=0.01$.

\section{Conclusion}

To our knowledge, this is the first study examining the possibilities of assistance provided by religious organizations to the victims of workplace violence, considering the aspects of gender and age. The results of this study provide new data contributing to a better understanding of circumstances that may influence the decision of persons who have experienced workplace violence to seek religious spiritual assistance. Of course, it should be noted that in this study, we did not aim to evaluate the quality and impact of the service, which is undoubtedly important, but drew attention to the extent to which victims of violence were aware of such possibility and circumstances that could encourage to apply for such assistance. In addition, we have shown that despite the current trends towards societal secularisation, values that are commonly associated with religion are still considerably accepted.

The empirical research enables to provide several insights.

First, demographic differences (gender and age of respondents) are those factors that explain both experiences of co-workers' destructive behaviour and circumstances of seeking religious spiritual assistance in more detail. On the one hand, the results of our study show that, contrary to what could have been expected, men reported experienced violence more often than women, which does not correspond to studies conducted in other countries (e.g., Salin \& Hoel, 2013; Lange et al., 2019; etc.). This discrepancy could be explained by a professional context because, as noted by Piquero et al. (2013), employees in different occupations also have different experiences of violence at work, meanwhile some occupations are characterized by different types of violence, caused by unique aggressors. In addition, Guay et al. (2015) found that men were more often at risk of physical violence. Our research sample included representatives of different professions, which could have influenced the result; moreover, the cultural context, which is worth investigating more thoroughly in the future, cannot be ruled out. On the other hand, it is clear that values and religious practices declared by religious organizations are more important to women than to men, as are the motives for seeking help, determined by circumstances. This confirms the trend observed in other studies that women are more inclined to seek assistance than men (Barbee et al., 1993; Rayner, 1999; Mulder et al., 2017; etc.) and, in the case of our study, this also applies to searches for religious spiritual assistance.

Second, although the values declared by religious organizations are more relevant to women than to men, women were more sensitive to contextual circumstances (e.g., the impossibility to receive other types of assistance, cost of service, and etc.) and to the relationship with the person providing assistance. In short, these are important barriers that can limit the use of assistance, despite the fact that women show greater favour.

Third, the age variable is significant only in two aspects, namely, of values and of awareness of information about religious spiritual assistance. Although younger age respondents experienced violence more often (especially in the age group of persons from 35 to 44 years old), which is in line with trends found in other studies, no statistically significant differences were found. It is far more important that the highest sensitivity to values was demonstrated by the oldest group of respondents, which had most information about spiritual 
assistance provided by religious organizations as well. Consequently, the older the persons, the stronger the acceptance of religious values, and simultaneously, with age, the amount of knowledge about the assistance provided is increasing. Thus, cherished values can be named as the strongest motive promoting the search for religious spiritual assistance, and strength is related to a certain age period, which should be taken into account when organizing assistance. Besides, attention must also be paid to the availability of information and channels through which it is obtained. Although there is a clergyman at the centre of the religious community, who usually (apart from secular counsellors) provides spiritual assistance, it is evident that it is secular people who more often participate in the dissemination of information about religious spiritual assistance, which is relevant for younger persons who have weaker ties to the religious community.

Thus, evaluating the research results, the main practice-oriented conclusion can be made: religious spiritual assistance for the victims of workplace violence may be attractive as a complementary means, but its organization requires flexibility and consideration of demographic variables. Although this study speaks about the situation in Lithuania, its results may be also relevant for other countries with high numbers of religious persons to whom religious values are important.

\section{Acknowledgement}

This research was funded by the European Social Fund under the No 09.3.3-LMT-K712-16-0144 "Development of Competences of Scientists, other Researchers and Students through Practical Research Activities" measure.

\section{References}

Abbott, R. (2012). Trauma, Compassion, and Community: Reconciling Opposites in the Interests of Post-traumatic Growth. Practical Theology, 5(1), 31-46. https://doi.org/10.1558/prth.v5i1.31

Acquadro Maran, D., Cortese, C. G., Pavanelli, P., Fornero, G., \& Gianino, M. M. (2019). Gender differences in reporting workplace violence: a qualitative analysis of administrative records of violent episodes experienced by healthcare workers in a large public Italian hospital. BMJ Open, 9:e031546. https://doi.org/10.1136/bmjopen-2019031546

Al-Krenawi, A., Graham, J. R., Dean, Y. Z., \& Eltaiba, N. (2004). Cross-National Study of Attitudes Towards Seeking Professional Help: Jordan, United Arab Emirates (UAE) and Arabs in Israel. International Journal of Social Psychiatry, 50(2), 102-114. https://doi.org/10.1177/0020764004040957

Barnes, R. P. (2010). Transforming Illness into Choice: A Spiritual Perspective. Journal of Pastoral Care \& Counseling, 64(3), 1-9. https://doi.org/10.1177/154230501006400306

Bilan, Y., Mishchuk, H., Samoliuk, N., \& Mishchuk, V. (2020). Gender discrimination and its links with compensations and benefits practices in enterprises. Entrepreneurial Business and Economics Review, 8(3), 189-204. https://doi.org/10.15678/EBER.2020.080311

Breen, M. J., \& Healy, A. (2014). Secularization in Ireland: Analyzing the Relationship between Religiosity and Demographic Variables in Ireland from the European Social Survey 2002-2012. The International Journal of Religion and Spirituality in Society, 3(4), 113125. https://doi.org/10.18848/2154-8633\%2FCGP\%2FV03I04\%2F59267

Brenner, R. E., Engel, K. E., Vogel, D. L., Tucker, J. R., Yamawaki, N. \& Lannin, D. G. (2018). Intersecting cultural identities and help-seeking attitudes: the role of religious 
commitment, gender, and self-stigma of seeking help. Mental Health, Religion \& Culture, 21(6), 578-587. https://doi.org/10.1080/13674676.2018.1519782

Brown, B., Myers, D., Casteel, C., \& Rauscher, K. (2020). Exploring differences in the workplace violence experiences of young workers in middle and late adolescence in the United States. Journal of Safety Research, 74, 263-269. https://doi.org/10.1016/j.jsr.2020.06.008

Burton, R. (2004). Spiritual pain: origins, nature and management. Contact, 143(1), 3-13. https://doi.org/10.1080/13520806.2004.11758977

Cetinkaya, F., Dur, N., Akbulut, Z., Eryalcin, O., \& Korkmaz, M. (2018). Evaluation of the Violence Experienced by Nurses of Different Generations and their Strategies for Coping with the Stress Resulting from Violence. International Journal of Caring Sciences, 11(3), 1775-1762.

Clinebell, H. (1988). Six Dimensions of Wholeness Centered in Spirit. In Spirit Centered Wholeness: Beyond the Psychology of Self. Lewiston/Queenston: The Edwin Mellen Press.

Crosby, J. W., \& Bossley, N. (2012). The religiosity gap: preferences for seeking help from religious advisors. Mental Health, Religion \& Culture, 15(2), 141-159. https://doi.org/10.1080/13674676.2011.561485

Deventer-Noordeloos, F., \& Srdjan, S. (2018). The lived religion of polish sex-trafficked survivors: a targeted investigation for practical theological analysis. Practical Theology, 11(5), 437-449. doi:10.1080/1756073X.2018.1536839

Doehring, C. (1992). Developing Models of Feminist Pastoral Counseling. Journal of Pastoral Care, 46(1), 23-31. https://doi.org/10.1177/002234099204600106

Dueck, A., \& Byron, K. (2011). Community, Spiritual Traditions, and Disasters in Collective Societies. Journal of Psychology and Theology, 39(3), 244-254. https://doi.org/10.1177/009164711103900307

Emdad, R., Alipour, A., Hagberg, J., \& Jensen, I. B. (2012). The impact of bystanding to workplace bullying on symptoms of depression among women and men in industry in Sweden: an empirical and theoretical longitudinal study. International Archives of Occupational and Environmental Health, 86(6), 709-716. https://doi.org/10.1007/s00420-012-0813-1

Fasanya, B. K., \& Dada, E. A. (2015). Caregivers' Concerns - Age-Group Issues on Workplace $\begin{array}{llll}\text { Violence. } & \text { Procedia } & \text { Manufacturing, 227-233. }\end{array}$ https://doi.org/10.1016/J.PROMFG.2015.07.133

Fischer, T., Van Reemst, L., \& De Jong, J. (2016). Workplace aggression toward local government employees: target characteristics. International Journal of Public Sector Management, 29(1), 30-53. https://doi.org/10.1108/IJPSM-05-2015-0100

Fleischmann, F., \& Phalet, K. (2018). Religion and national identification in Europe: Comparing Muslim youth in Belgium, England, Germany, the Netherlands, and Sweden. Journal of Cross-Cultural Psychology, 49(1), 44-61. https://doi.org/10.1177/0022022117741988

Freire, J., Moleiro, C., \& Rosmarin, D. H. (2016). Calling for Awareness and Knowledge: Perspectives on Religiosity, Spirituality and Mental Health in a Religious Sample from Portugal (a Mixed-Methods Study). Open Theology, 2(1), 681-699. https://doi.org/10.1515/opth-2016-0053

Friis, K., Larsen, F. B., \& Lasgaard, M. (2018). Physical violence at work predicts healthrelated absence from the labor market: A 10-year population-based follow-up study. Psychology of Violence, 8(4), 484-494. https://doi.org/10.1037/vio0000137 
Guay, S., Goncalves, J., \& Jarvis, J. (2015). A systematic review of exposure to physical violence across occupational domains according to victims' sex. Aggression and Violent Behavior, 25(Part A), 133-141. https://doi.org/10.1016/J.AVB.2015.07.013

Gubi, P. M. (2011). A Qualitative Exploration of the Similarities and Differences between Counselling and Spiritual Accompaniment. Practical Theology, 4(3), 339-358. https://doi.org/10.1558/prth.v4i3.339

Guetto, R., Luijkx, R., \& Scherer, S. (2015). Religiosity, gender attitudes and women's labour market participation and fertility decisions in Europe. Acta Sociologica, 58(2), 155-172. https://doi.org/10.1177/0001699315573335

Hagmaier, G. (2012). "Spiritual Direction and Non-Directive Counseling". Proceedings of the Catholic Theological Society of America, 18 (October). https://ejournals.bc.edu/index.php/ctsa/article/view/2552

Jalali, A., Jaafar, M., \& Hidzir, N. I. (2020). Indirect effect of workplace bullying on emotional exhaustion through job insecurity among Malaysian workers: The buffering role of religion. Journal of Islamic Accounting and Business Research, 11(7), 1325-1342. https://doi.org/10.1108/JIABR-11-2018-0182

Jaradat, Y., Nielsen, M. B., Kristensen, P., Nijem, K., Bjertness, E., Stigum, H., \& BastPettersen, R. (2016). Workplace aggression, psychological distress, and job satisfaction among Palestinian nurses: A cross-sectional study. Applied Nursing Research, 32, 190198. https://doi.org/10.1016/j.apnr.2016.07.014

Jóhannsdóttir, H. L., \& Ólafsson, R. F. (2004). Coping with bullying in the workplace: the effect of gender, age and type of bullying. British Journal of Guidance \& Counselling, 32(3), 319-333. https://doi.org/10.1080/03069880410001723549

Keating, A. M., \& Fretz, B. R. (1990). Christians' anticipations about counselors in response to counselor descriptions. Journal of Counseling Psychology, 37(3), 293-296. https://doi.org/10.1037/0022-0167.37.3.293

Lanctôt, N., \& Guay, S. (2014). The aftermath of workplace violence among healthcare workers: A systematic literature review of the consequences. Aggression and Violent Behavior, 19(5), 492-501. https://doi.org/10.1016/j.avb.2014.07.010

Lange, S., Burr, H., Conway, P. M., \& Rose, U. (2019). Workplace bullying among employees in Germany: prevalence estimates and the role of the perpetrator. International Archives of Occupational and Environmental Health, 92(2), 237-247. https://doi.org/10.1007/s00420-018-1366-8

Lee, K. H. (2011). The Role of Spiritual Experience, Forgiveness, and Religious Support on the General Well-Being of Older Adults. Journal of Religion, Spirituality \& Aging, 23(3), 206-223. https://doi.org/10.1080/15528030.2011.533398

Li, M., Liu, J., Zheng, J., Liu, K., Wang, J., Ross, A. M., Liu, X., Fu, X., Tang, J., Chen, C., \& You, L. (2020). The Relationship of Workplace Violence and Nurse Outcomes: Gender Difference Study on A Propensity Score Matched Sample. Journal of Advanced Nursing, 76(2), 600-610. https://doi.org/10.1111/jan.14268

Mayers, C., Leavey, G., Vallianatou, C., \& Barker, C. (2007). How Clients with Religious or Spiritual Beliefs Experience Psychological Help-Seeking and Therapy: A Qualitative Study. Clinical Psychology and Psychotherapy, 14(4), 317-327. https://doi.org/10.1002/cpp.542

Mitchell, J. R., \& Baker, M. (2000). Religious commitment and the construal of sources of help for emotional problems. The British Journal of Medical Psychology, 73(3), 289-301. https://doi.org/10.1348/000711200160471

Moreno, O., Nelson, T., \& Cardemil, E. V. (2017). Religiosity and attitudes towards professional mental health services: analysing religious coping as a mediator among 
Mexican origin Latinas/os in the southwest United States. Mental Health, Religion \& Culture, 20(7), 626-637. https://doi.org/10.1080/13674676.2017.1372735

Mulder, R., Bos, A. E. R., Pouwelse, M., \& van Dam, K. (2017). Workplace mobbing: How the victim's coping behavior influences bystander responses. The Journal of Social Psychology, 157(1), 16-29. https://doi.org/10.1080/00224545.2016.1152213

Mulder, R., Pouwelse, M., Lodewijkx, H., \& Bolman, C. (2014). Workplace mobbing and bystanders' helping behaviour towards victims: The role of gender, perceived responsibility and anticipated stigma by association. International Journal of Psychology, 49(4), 304-312. https://doi.org/10.1002/ijop.12018

Notelaers, G., Van der Heijden, B., Hoel, H., \& Einarsen, S. (2019). Measuring bullying at work with the short-negative acts questionnaire: identification of targets and criterion validity. Work \& Stress, 33(1), 58-75. https://doi.org/10.1080/02678373.2018.1457736

Opatrný, M. (2020). "Caritas theory" as theological discourse within education in social work? Journal of Religion \& Spirituality in Social Work: Social Thought, 39(3), 299-323. https://doi.org/10.1080/15426432.2020.1780182

Piquero, N. L., Piquero, A. R., Craig, J. M., \& Clipper, S. J. (2013). Assessing research on workplace violence, 2000-2012. Aggression and Violent Behavior, 18(3), 383-394. https://doi.org/10.1016/J.AVB.2013.03.001

Raišienè, A. G., Rapuano, V., Dőry, T., \& Varkulevičiūtè, K. (2021). Does telework work? Gauging challenges of telecommuting to adapt to a "new normal". Human Technology, 17(2), 126-144. https://doi.org/10.14254/1795-6889.2021.17-2.3

Requena, M., \& Stanek, M. (2013). Secularization in Poland and Spain after the democratic transition: A cohort analysis. International Sociology, 28(1), 101-184. https://doi.org/10.1177/0268580912466551

Rodrigues, L. R., Nader, I. D., e Silva, A. T. M., Tavares, D. M. S., de Assunção, L. M., \& Molina, N. P. F. M. (2017). Spirituality and religiosity related to socio-demographic data of the elderly population. Northeast Network Nursing Journal, 18(4), 429-436. https://doi.org/10.15253/2175-6783.2017000400002

Salin, D. (2015). Risk factors of workplace bullying for men and women: The role of the psychosocial and physical work environment. Scandinavian Journal of Psychology, 56(1), 69-77. https://doi.org/10.1111/sjop.12169

Salin, D., \& Hoel, H. (2013). Workplace bullying as a gendered phenomenon. Journal of Managerial Psychology, 28(3), 235-251. https://doi.org/10.1108/02683941311321187

Schultz, M., Czamanski-Cohen, J., Bentur, N., Mohsen-Byadsi, S., Artsieli, Y., \& Bar-Sela, G. (2020). Multidisciplinary Staff Perspectives on the Integration of Spiritual Care in a New Setting: Israel. Palliative and Supportive Care, 18(4), 431-436. https://doi.org/10.1017/s1478951519000877

Schuster, M. A., Stein, B. D., Jaycox, L. H., Collins, R. L., Marshall, G. N., Elliott, M. N., Zhou, A. J., Kanouse, D. E., Morrison, J. L., \& Berry, S. H. (2001). A National Survey of Stress Reactions after the September 11, 2001, Terrorist Attacks. The New England Journal of Medicine, 345(20), 1507-1512. https://psycnet.apa.org/doi/10.1056/NEJM200111153452024

Sørgaard, K. W., \& Sørensen, T. (2004). The Church and community psychiatric services in a region of northern Norway. Social Psychiatry and Psychiatric Epidemiology, 31(5), 266271. https://doi.org/10.1007/BF00787919

Spector, P. E., Zhou, Z. E., \& Che, X. X. (2014). Nurse exposure to physical and nonphysical violence, bullying, and sexual harassment: A quantitative review. International Journal of Nursing Studies, 51(1), 72-84. https://doi.org/10.1016/j.ijnurstu.2013.01.010 
Statistics Lithuania. (n.d.). Ethnicity, mother tongue and religion. http://statistics.bookdesign.lt/dalis_04.pdf

Stirling, I. (2019). Deep silences: reclaiming silence as a locus of the sacred. Practical Theology, 13(3), 259-276. https://doi.org/10.1080/1756073X.2019.1683313

Tenhunen, S. (2019). Mobile media, gender, and power in rural India. Human Technology, 15(2), 181-201. https://doi.org/10.17011/ht/urn.201906123155

Turner, C. (2017). Numinous physiology: A theological reflection on angels, trauma and spirituality. Practical Theology, 10(4), 337-350. https://doi.org/10.1080/1756073X.2017.1330052

Tvaronavičienè, M., Mazur, N., Mishchuk, H., \& Bilan, Y. (2021). Quality of life of the youth: assessment methodology development and empirical study in human capital management. Economic Research-Ekonomska Istraživanja, 1-18. DOI:10.1080/1331677X.2021.1956361

Van den Bossche, S., Taris, T., Houtman, I., Smulders, P., \& Kompier, M. (2013). Workplace violence and the changing nature of work in Europe: Trends and risk groups. European Journal of Work and Organizational Psychology, 22(5), 588-600. https://doi.org/10.1080/1359432X.2012.690557

Van der Noll, J., Rohmann, A., \& Saroglou, V. (2018). Societal level of religiosity and religious identity expression in Europe. Journal of Cross-Cultural Psychology, 49(6), 959-975. https://doi.org/10.1177/0022022117737302

Vartia, M., \& Hyyti, J. (2002). Gender differences in workplace bullying among prison officers. European Journal of Work and Organizational Psychology, 11(1), 113-126. https://doi.org/10.1080/13594320143000870

Vveinhardt, J., \& Deikus, M. (2021). Search for spiritual assistance in religious organizations: what are the motives of persons who have experienced destructive relationships at work?. Frontiers in Psychology, 12, 702284. doi: 10.3389/fpsyg.2021.702284 